\title{
Ruth Suckow: a Calendar of Letters (II)
}

\author{
F R A N K PAL UKA
}

[This list concludes the calendar of letters begun in the previous issue. These letters form part of a considerably larger collection of Miss Suckow's papers, presented to The University of Iowa Libraries by Mr. Ferner Nuhn. Appreciation is hereby expressed to Mr. Nuhn and to those whose gifts have added to the collection: Mrs. Clifton Woodhams, Mrs. Clara Seifert Roberts, Miss Evelyn Cady, Professor John T. Frederick, Alfred A. Knopf, Inc., the Viking Press, and Rinehart \& Company (now Holt, Rinehart \& Winston, Inc.).]

1932

Fred A. Robbins to R. S. Chicago, 16 February 1932. Asking whether there is any connection between a character in The Bonney Family and a woman in Grinnell, Iowa. T.L.S. 1 p.

Pickens Johnson to R. S. Nashville, Tennessee, 7 May 1932. Expressing pleasure with her story "An Elegy for Alma's Aunt Amy." A.L.S. 2 p.

1933

Anne Parrish to R. S. Manchester-in-the-Mountains, Vermont, 26 August [1933]. Inviting Miss Suckow to lunch or dinner. A.L.S. 1 p.

James Norman Hall to Edward C. Mabie. Papeete, Tahiti, 19 November 1933. Concerning the possibility of an experimental production of a play by Hall, based on Miss Suckow's story "Uprooted." T.L.S. 1 p.

1934

R. S. to John [Farrar]. Peterborough, New Hampshire, 10 August 1934. Objecting to the proposed jacket design for The Folks. A.L.S. 3 p.

[John Farrar] to R. S. [New York] 28 September 1934. Concerning the anticipated success of The Folks; hopes for mutual understanding between author and publisher. Autograph draft unsigned, $4 \mathrm{p}$.

James E. Downing to R. S. Des Moines, Iowa, 1 October 1934. Enclosing the text of a sermon by Miss Suckow's father, delivered in Fort Dodge, Iowa, circa 1908. T.L.S. 1 p.

Dorothy Canfield Fisher to R. S. Arlington, Vermont, 7 October [1934]. Concerning her enthusiasm for The Folks; compares Miss Suckow with Vermeer in the use of luminous light and detail. T.L.S. 2 p. 
Carty Ranck to R. S. Boston, 13 October 1934. Congratulating her on The Folks; reference to Edwin Arlington Robinson. T.L.S. 1 p.

Eliza T. Willets to R. S. New York, 24 October 1934. Praising The Folks; remarks on various characters in the book. T.L.S. 2 p.

Anne Parrish to R. S. Englewood, New Jersey, 28 October 1934. Expressing her enthusiasm for The Folks; finds a resemblance to D. H. Lawrence in Miss Suckow's descriptions of flowers and growing things, and praises her honesty. T.L.S. 2 p.

G. A. Stead to R. S. Covina, Califonia, 3 November 1934. Commenting on The Folks. A.L.S. 3 p.

Westberg Family to R. S. Bellflower, California, n.d. Concerning their enjoyment of The Folks; suggests that there is an error in the description of preparations for Dorothy's wedding. Typescript copy. $1 \mathrm{p}$.

Ruth E. Anderson to R. S. [New York] 14 November 1934. Acknowledging receipt of corrections for the next edition of The Folks. Carbon typescript. 1 p.

Walter H. Wilcox to Farrar and Rinehart. New York, 5 November 1934. Suggesting that one of Miss Suckow's descriptions in The Folks is in error. T.L.S. 1 p. with carbon of reply.

Douglas Bement to John Farrar. Arlington, Virginia [circa 20 November 1934]. Expressing thanks for a copy of The Folks; says he has been impressed by all of Miss Suckow's works. T.L.S. 1 p.

Marya Gregory to R. S. [New York] [9 December 1934]. Concerning Mrs. Gregory's work, her health and her husband Horace; mentions James $T$. Farrell; comments on the news from Russia and famine in the Ukraine. A.L.S. 4 p.

1935

Clara Seifert Roberts to W. J. Suckow. Kansas City, Missouri, 7 January 1935. Concerning some drawings done by R. S. as a child in Hawarden, Iowa. T.L.S. 1 p.

Rose Wilder Lane to R. S. Mansfield, Missouri, 6 March 1935. Expressing her enthusiasm for The Folks. T.L.S. 1 p.

Helen Jo Crissman to R. S. Kansas City, Missouri, 12 April 1935. Expressing her pleasure with The Folks. T.L.S. 1 p.

Thomas P. Beyer to R. S. Saint Paul, Minnesota, 1 May 1935. Thanking her for her criticism of stories by students at Hamline University. T.L.S. 1 p.

Jule Brousseau to R. S. Ridgefield, New Jersey, 23 September 1935. Remarking on The Folks. T.L.S. 2 p.

Evelyn Metcalfe to R. S. Walberswick, Suffolk, England, 30 September 1935. Describing Jove cottage and Walberswick village; mention of A. E. Coppard and his wife, and a visit from Morton Zabel; remarks on Horace Gregory and James T. Farrell. T.L. 5 p.

1939

Adelaide A. Sherer to R. S. [New York] 27 June 1939. Asking about the progress of her novel. Carbon typescript. 1 p. 
R. S. to Caroline Woodhams. Cedar Falls, Iowa, 2 January 1941. Concerning a gold bracelet given to R. S. by Mrs. Woodhams' mother and its loss in a New York fire; references to her father and to the trip she and her husband made to Scandinavia and England two summers ago. A.L.S. 4 p.

R. S. to John Farrar. Cedar Falls, Iowa, 20 February 1941. Concerning the compressing of the second part of New Hope into a final chapter; mentions a forthcoming visit and lecture in Cedar Falls by Sigrid Undset. T.L.S. 2 p. with 13-line autograph postscript concerning the minister in New Hope.

John Farrar to R. S. [New York] 24 February 1941. Hoping that her novel will be ready by May or June. Carbon typescript. 1 p.

Ferner Nuhn to John Farrar. Cedar Falls, Iowa, 24 June 1941. Concerning the revised jacket for New Hope; mentions that Miss Suckow is rewriting and expanding the second part of her manuscript. T.L.S. 2 p. with carbon of reply.

Ferner Nuhn to John Farrar. Cedar Falls, Iowa, 5 August 1941. Concerning the revised form of New Hope; it preserves the original idyll and dispenses with a later story or sequel. T.L.S. 1 p.

\section{2}

Wm. James Fadiman to Ellan Mcllvaine. [np] 13 February 1942. Explaining why New Hope is unsuitable for film production. Carbon typescript. $1 \mathrm{p}$.

John Farrar to Sterling North. [New York] 28 March 1942. Concerning their divergent opinions of New Hope. Carbon typescript. 2 p. with typed draft.

R. S. to Caroline Woodhams. Cedar Falls, Iowa, 28 April [1942?] Concerning points of resemblance between characters and places in her novel New Hope and actual people and towns; remarks that old landmarks in Algona, Iowa, seem to have changed. T.L.S. 2 p.

\section{3}

Adelaide A. Sherer to R. S. New York, 14 April 1943. Stating that the Doubleday Doran Dollar Book Club is taking 2000 of some 6000 warehouse copies of New Hope; reference to the death of Stephen Benét. Carbon typescript. 1 p.

\section{5}

R. S. to John T. Frederick. Cedar Falls, Iowa, 18 October 1945. Concerning his request to reprint a portion of "The Folk Idea in American Life"; mentions that she has been writing intensively. T.L.S. 2 p.

R. S. to R. E. Ellsworth. Cedar Falls, Iowa, 5 December 1945. Concerning the preservation of her manuscripts; states that she seldom keeps notes and early drafts of her work. T.L.S. 1 p. 
R. S. to Adelaide Sherer. Cedar Falls, Iowa, 28 January 1946. Consenting to the use of a simplified version of "A Start in Life" in experimental classes at The University of Texas. T.N.S. 1 p.

R. S. to Adelaide Sherer. Cedar Falls, Iowa, 14 May 1946. Concerning the use of her story "Golden Wedding" in an anthology; comments on three novels she is reading: The Son of the Lost Son, The Hucksters, and Dreiser's The Bulwark. T.L.S. 1 p.

Marguerite J. Reese to R. S. [New York] 22 November 1946. Concerning an NBC radio reading of "Just Him and Her" by Nelson Olmstead. Carbon typescript. 1 p. with five related items.

1948

R. S. to Marguerite J. Reese. Tucson, Arizona, 7 April 1948. Concerning a radio broadcast of "Just Him and Her." A.L.S. 1 p. with five related items.

Marguerite J. Reese to Ellan McIlvaine. New York, 9 April 1948. Referring a request from radio station KUOM to broadcast a radio adaption of The Folks; mentions that Miss Suckow has not been well and expresses interest in having another book from her. Carbon typescript. 1 p. with typed note.

Ellan McIlvaine to Marguerite Reese. New York, 12 April 1948. Inquiring about the possibility of a new edition of The Folks; refers to Miss Suckow's talks and seminars. T.L.S. 1 p.

Stanley M. Rinehart, Jr. to Ellan McIlvaine. [New York] 27 April 1948. Hoping that someday Rinehart can reissue The Folks; suggests that costs are too high at present. Carbon typescript. 1 p.

1949

R. S. to Adelaide Sherer. Tucson, Arizona, 10 January 1949. Concerning a request to reprint her story "Just Him and Her." A.L.S. 1 p. with four related carbons.

R. S. to Caroline Woodhams. [Tucson, Arizona?] [7 December 1949?] Acknowledging a Christmas letter. A.N.S. 2 p.

1950

Diarmuid Russell to John Selby. New York, 26 April 1950. Forwarding the manuscript of Sequel by a Later Hand; notes a resemblance to Willa Cather in Miss Suckow's mood and attitude toward life. T.L.S. 1 p.

John Selby to R. S. New York, 19 May 1950. Concerning a manuscript submitted by Miss Suckow; suggests that the long story entitled Sequel by a Later Hand be replaced by additional short stories. Carbon typescript. 1 p. with three related memos.

R. S. to John Selby. Tucson, Arizona, 25 May 1950. Acknowledging his letter of 19 May. T.C.S. with reply.

R. S. to John Selby. Tucson, Arizona, 7 June 1950. Suggesting that her manuscript might be supplemented either by additional stories which she 
has in unfinished rough form or by an autobiographical sketch which she has in preliminary draft. T.L.S. $1 \mathrm{p}$.

John Selby to R. S. New York, 20 June 1950. Asking Miss Suckow to make the decision as to how she supplements her manuscript, but indicating a preference for the autobiographical sketch. Carbon typescript. $1 \mathrm{p}$.

R. S. to John Selby. Tucson, Arizona, 12 July 1950. Concerning her autobiographical sketch. T.L.S. 1 p.

Diarmuid Russell to John Selby. New York, 17 July 1950. Asking that the manuscript of Winterset be returned to Miss Suckow; mentions that she is working on an autobiographical sketch to replace it. T.L.S. 1 p. with carbon of reply.

John Selby to R. S. [New York] 19 July 1950. Concerning the novelette he is returning. Carbon typescript. $1 \mathrm{p}$.

R. S. to John Selby. Tucson, Arizona, 7 August 1950. Concerning the progress of her narrative. T.L.S. 1 p. with carbon of reply.

R. S. to John Selby. Tucson, Arizona, 25 September 1950. Concerning progress on her narrative, now three-fourths completed; mentions a vacation trip to northern California. T.L.S. 1 p.

R. S. to John Selby. Tucson, Arizona, 20 November 1950. Stating that she has finished the autobiographical piece and suggesting the title A Memoir. T.L.S. 1 p. with carbon of reply.

Diarmuid Russell to John Selby. New York, 28 December 1950. Forwarding Miss Suckow's Memoir. T.N.S. 1 p.

1951

John Selby to R. S. [New York] 5 February 1951. Questioning whether A Memoir should begin or end the new book. Carbon typescript. $1 \mathrm{p}$.

Ferner Nuhn to John Selby. Tucson, Arizona, 12 February 1951. Indicating that Miss Suckow has no preference concerning the order of A Memoir; mentions a visit to Whittier, California. A.C.S.

John Selby to Diarmuid Russell. New York, 28 March 1951. Concerning terms of the contract for Some Others and Myself. Carbon typescript. 1 p. with three related items.

Diarmuid Russell to John [Selby]. New York, 2 April 1951. Indicating that Miss Suckow wants to discuss certain points in her contract. T.L.S. 1 p. Stanley M. Rinehart, Jr. to Diarmuid Russell. New York, 3 April 1951. Enclosing contracts for a new book by R. S. T.L.S. 1 p. with three related items.

R. S. to John Selby. Tucson, Arizona, 17 April 1951. Concerning the possibility of separately reprinting A Memoir; mentions her interest in Dr. McCord's book My Patients Were Zulus. T.L.S. 1 p. with carbon of reply.

Stanley M. Rinehart, Jr. to R. S. New York, 8 May 1951. Acknowledging receipt of signed contract and enclosing an advance on royalty. Carbon typescript. $1 \mathrm{p}$.

R. S. to John Selby. Tucson, Arizona, 12 May 1951. Suggesting Some Others 
and Myself as the title for her book. T.N.S. 1 p. with carbons of his inquiry and reply.

R. S. to Marguerite J. Reese. Tucson, Arizona, 26 June 1951. Concerning an NBC radio broadcast of Miss Suckow's "Wanderers." A.L.S. 2 p. with five related items.

R. S. to Marguerite J. Reese. Cedar Falls, Iowa, 9 July 1951. Indicating her sources for seven quotations. A.L.S. 2 p. with carbon of reply.

R. S. to Marguerite J. Reese. Cedar Falls, Iowa, 15 July 1951. Concerning previous publication of certain stories included in her new book; suggests that "Ollie and Mrs. Vogel" might offer the basis for a motion picture scenario; comments on the radio broadcast of "Wanderers." A.L.S. 2 p. with carbon of reply, 2 p.

Diarmuid Russell to Marguerite J. Reese. New York, 20 July 1951. Concerning the submission to magazines of certain stories by Miss Suckow. T.L.S. 1 p. with three related carbons.

R. S. to Marguerite J. Reese. Earlville, Iowa, 24 July 1951. Concerning the list of stories sold and submitted; mentions that she is spending a few days in the small town where she once kept bees; mentions a visit from Margaret Stewart, who is preparing a doctoral thesis on Miss Suckow's writing. A.C.S. with carbon of reply and related memo.

Marguerite J. Reese to R. S. New York, 16 August 1951. Concerning copyright assignments of the stories to be included in Some Others and $M y$ self. Carbon typescript, 2 p. with carbon memo.

R. S. to Marguerite J. Reese. Tucson, Arizona, 23 August 1951. Indicating the magazines to which certain stories were submitted; remarks that she considers "Eltha" one of her best stories. T.L.S. 1 p. with carbon of reply.

R. S. to Marguerite J. Reese. Tucson, Arizona, 7 September 1951. Remarking on Margaret Kennedy's book Lucy Carmichael. T.L.S. 1 p. with carbon of reply.

R. S. to Marguerite J. Reese. Tucson, Arizona, 18 September 1951. Concerning corrections in the proof of Some Others and Myself; mentions Miss Stewart's injury in an automobile accident. T.L.S. 1 p.

Adelaide A. Sherer to R. S. [New York] 27 November 1951. Sending author's copies of the new book. Carbon typescript. $1 \mathrm{p}$.

R. S. to Adelaide Sherer. Tucson, Arizona, 7 December 1951. Ordering ten extra copies of Some Others and Myself. T.C.S.

R. S. to Grace Wormer. Tucson, Arizona, 8 December 1951. Concerning the manuscript of Some Others and Myself; mentions that the parts were written at widely different times. T.L.S. 1 p.

John Selby to R. S. [New York] 27 December 1951. Concerning the jacket of Some Others and Myself and the proof of an advertisement. Carbon typescript. 1 p.

1952

John Selby to R. S. [New York] 3 January 1952. Enclosing proofs of ad- 
vertisements for Some Others and Myself and a review. Carbon typescript. $1 \mathrm{p}$.

R. S. to Stanley and Frederick Rinehart. Tucson, Arizona, 7 January 1951 [i.e. 1952?] Thanking them for a specially-bound copy of Some Others and Myself. A.N.S. 2 p.

R. S. to John Selby. Tucson, Arizona, 11 January 1952. Concerning two newspaper notices of her book. T.L.S. 1 p.

R. S. to John Selby. Tucson, Arizona, 4 February 1952. Concerning an advertisement for Some Others and Myself; comments on Victoria Lincoln's book Out of Eden. T.L.S. I p. with related memo and carbon of reply.

R. S. to Marguerite J. Reese. Tucson, Arizona, 3 March 1952. Concerning letters she has received from Assen Tzanhov and others. T.L.S. 1 p. with carbon of reply.

Marguerite J. Reese to R. S. [New York] 5 March 1952. Concerning copyright renewal of the stories collected in Iowa Interiors. Carbon typescript. 2 p.

R. S. to Marguerite J. Reese. Tucson, Arizona, 21 March 1952. Indicating where each of the stories in Iowa Interiors had its first magazine publication. T.L.S. 1 p.

R. S. to Marguerite J. Reese. Claremont, California, 3 April 1952. Concerning her recent move to Claremont; mentions Dorothy Baker and Edward Weissmiller. T.L.S. 1 p.

Marguerite J. Reese to R. S. [New York] 11 April 1952. Concerning an edition of A Memoir for the Christian Herald's Family Bookshelf. Carbon typescript. $1 \mathrm{p}$.

Marguerite J. Reese to R. S. [New York] 27 August 1952. Sending a copy of the Christian Herald's Family Bookshelf gift edition of A Memoir. Carbon typescript. $1 \mathrm{p}$.

R. S. to Grace Wormer. Claremont, California, 10 September 1952. Concerning the manuscript of A Memoir. T.L.S. 1 p.

R. S. to Grace Wormer. Claremont, California, 22 September 1952. Conveying the address of Miss Stewart in Kentucky. T.C.S.

R. S. to Marguerite J. Reese. Claremont, California, 20 October 1952. Concerning a request to reprint "A Start in Life" with certain modifications. T.L.S. 1 p. with eight related items.

R. S. to Opal Suckow. Claremont, California, 28 October 1952. Concerning a request for photographs for use in an exhibit; mentions her copies of English, Danish, Norwegian, and Swedish editions of some of her books, including an inscribed copy of Cora sent to her by Sigrid Undset. Typescript copy. $1 \mathrm{p}$.

1953

R. S. to Caroline Woodhams. Claremont, California, 13 February 1953. Concerning her pleasure with the Claremont community; refers to her forthcoming article on Harriet Beecher Stowe. T.L.S. 2 p. 
R. S. to Evelyn Cady. Claremont, California, 20 February 1953. Recalling people and events in Algona, Iowa, at the time Miss Suckow and Miss Cady were classmates in the first grade; remarks on the Revised Version of the Bible and quotes a poem by Emily Dickinson. T.L.S. 4 p.

R. S. to Marguerite J. Reese. Claremont, California, 16 March 1953. Asking that Rinehart \& Company cooperate with Mrs. Wald, who is doing a thesis on Miss Suckow at Miami University, Oxford, Ohio. T.L.S. with carbon typescript of reply. $1 \mathrm{p}$.

Theodore S. Amussen to R. S. [New York] 7 May 1953. Enclosing a royalty statement and commenting on his work with Rinehart \& Co. Carbon typescript, $1 \mathrm{p}$.

R. S. to Caroline Woodhams. [Claremont, California] [circa 1953?] Hoping that Mrs. Woodhams will visit in Claremont. A.N.S. I p.

R. S. to Grace Wormer. Claremont, California, 9 June 1953. Replying to a request for biographical information about her husband, Ferner Nuhn; mentions a proposed sequel to his book The Wind Blew from the East, to be entitled Emerson, Lincoln and Whitman. T.L.S. I p. with autograph postscript.

R. S. to Caroline Woodhams. Claremont, California, 2 October 1953. Concerning a visit to the Los Angeles County fair; remarks on the renewal of old friendships; reference to her forthcoming article in Midland Schools. T.L.S. 2 p.

1954

R. S. to Caroline Woodhams. Claremont, California, 7 May 1954. Concerning the absence of her husband on a three-month speaking tour; records her reactions to the McCarthy-Army hearings on TV and mentions her old Grinnell friend Joseph Welch. T.L.S. 2 p.

R. S. to Marguerite J. Reese. Claremont, California, 14 June 1954. Concerning the possibility of a trip to Philadelphia and New York in August or September; mentions that she is working on a novel. T.L.S. 2 p. with carbon of reply.

1955

R. S. to Caroline Woodhams. Claremont, California, 17 August 1955. Concerning the death of a relative in Nebraska and plans for a trip east in October; mentions a visit to the LeCrons at Chokecherry Gulch. A.L.S. 5 p. on one folded sheet.

R. S. to Caroline Woodhams. Claremont, California, 9 September 1955. Concerning the illness of Mrs. Woodhams' father. A.N.S. 1 p.

R. S. to Caroline and Clifton Woodhams. [Claremont, California] [December 1955] Concerning her ten-day visit on a Nebraska farm; praises the great helpfulness of the farm neighbors and comments on their religious attitudes and practices. A.L.S. 4 p. on one folded sheet. 
R. S. to Grace Wormer. Claremont, California, 19 November 1956. Concerning a request from the New York Public Library for one of Miss Suckow's manuscripts. T.L.S. 2 p.

R. S. to Caroline Woodhams. [Claremont, California] n.d. Concerning her illness and slow improvement; mentions that she has a book half finished. A.L.S. 3 p. on folded sheet.

\section{7}

R. S. to Marguerite J. Reese. Claremont, California, 19 January 1957. Thanking her for a package of books, including The Fur Person; remarks on her cat named Chris; mentions that she is revising a short novel; alludes to a request from the New York Public Library for a Suckow manuscript for their Emma Mills Collection. T.L.S. 1 p. with carbon of reply.

R. S. to Caroline Woodhams. Claremont, California, 8 August 1957. Concerning a proposed trip to McMinville, Oregon. A.N.S. 3 p.

\section{8}

R. S. to Pascal Covici. Claremont, California, 20 November 1958. Concerning cuts and revisions she has made in the manuscript of The John Wood Case. T.L.S. 2 p.

R. S. to Pascal Covici. Claremont, California, 6 December 1958. Agreeing to send some material he has requested. A.N.S. 1 p.

R. S. to Pascal Covici. Claremont, California, 4 March 1959. Concerning a mention of The John Wood Case in The Des Moines Register; alludes to her work in progress, a novel she has had in mind for many years. T.L.S. 1 p.

R. S. to Pascal Covici. Claremont, California, 6 April 1959. Concerning a statement on the dust jacket of The John Wood Case; suggests there is no close parallel between this story and a person mentioned in $A$ Memoir. T.L.S. 1 p.

R. S. to Pascal Covici. Claremont, California, 28 May 1959. Suggesting an advertisement of The John Wood Case in The Des Moines Register; alludes to an unfavorable review in this newspaper. T.L.S. 1 p.

R. S. to Pascal Covici. Claremont, California, 8 June 1959. Concerning promotion of The John Wood Case. T.L.S. 1 p.

R. S. to Caroline Woodhams. Claremont, California, 12 August 1959. Concerning the reception of The John Wood Case; mentions her husband's work, her birthday, and a visit to Grant Wood's sister. T.L.S. 4 p.

R. S. to Pascal Covici. Claremont, California, 21 September 1959. Concerning her novel in progress, tentatively called Some Boundless Thing; briefly characterizes the central figure, Nanne Cameron. T.L.S. 1 p. with autograph postscript. 
R. S. to Caroline Woodhams. Claremont, California, 5 October 1959. Concerning her husband's work; mentions Khrushchev's visit to the farm of her friends the Roswell Garsts near Coon Rapids, Iowa. T.L.S. 2 p.

R. S. to Marcus A. McCorison. Claremont, California, 12 October 1959. Concerning her manuscripts; mentions the summer she spent in Robert Frost's home and her friendship with Dorothy Canfield Fisher. T.L.S. 2 p.

R. S. to Marcus A. McCorison. Claremont, California, 5 November 1959. Concerning her intention that her papers and manuscripts go to The University of Iowa Library. T.L.S. 1 p.

1960

Ferner Nuhn to Claremont, California, February 1960. Concerning R. S.'s last year and expressing thanks for sympathy at the time of her death; mentions a novel she left unfinished entitled A Boundless Thing. Duplicated typescript. $1 \mathrm{p}$.

Louis H. Suckow to Ferner Nuhn. Mason City, Iowa, 19 June 1960. Concerning R. S.'s ancestors. A.L.S. 2 p.

Ferner Nuhn to Friends. Claremont, California, December 1960. Concerning his activities during the year; mentions the publication in the Iowan magazine of selections from a notebook by R. S. Duplicated typescript. $1 \mathrm{p}$. with autograph postscript. 